Navigation Physics 3(1)(2021)
Navigation Physics
Journal of Physics Education

\title{
Penerapan Rangkaian Konsep Pembelajaran \\ Untuk Meningkatkan Hasil Belajar Fisika Pada Pokok Bahasan Gerak Lurus Siswa Kelas VIII 6 SMP Negeri 87 Jakarta Selatan
}

\author{
Nyimas Farida Iriani \\ SMP Negeri 87 Jakarta Selatan \\ *E-mail: irianifaridanyimas@gmail.com
}

\begin{tabular}{ll}
\hline Info Artikel & Abstract \\
\hline Sejarah Artikel: & The learning activity shows students only accept the facts that must be \\
Diterima Mei 2019 & memorized and still lack student involvement because it is almost always \\
Disetujui June 2017 & taught by lecture methods. The purpose of this study is to find out the \\
Dipublikasikan July 2017 & application of a series of concepts in learning can improve the results of \\
& learning physics on the subject of straight motion students grade VIII.6 \\
\hline Keywords: & SMP Negeri 87 South Jakarta. This research is a Class Action Research \\
Physics learning, learning outcome, & (PTK) conducted in the 2020-2021 school year with the research subjects of \\
motion material & grade VIII 6 students numbering 35 students. The data collection \\
& techniques used are tests and observations. Based on the results of the \\
& study, it can be concluded that the application of a series of concepts in \\
learning with learning steps in accordance with RPP can improve learning \\
outcomes, both cognitive, affective and psychomotor students. Students \\
seem enthusiastic and actively studying physics in the classroom.
\end{tabular}

How to Cite: Iriani, N. F. (2021). Penerapan Rangkaian Konsep Pembelajaran Untuk Meningkatkan Hasil Belajar Fisika Pada Pokok Bahasan Gerak Lurus Siswa Kelas VIII 6 SMP Negeri 87 Jakarta Selatan. Navigation Physics: Journal Physics Education, 3 (1), 39-44.

\section{PENDAHULUAN}

Pembelajaran Fisika adalah pembelajaran yang membutuhkan pemahaman yang dapat dibuktikan secara fisis dan mempelajari peristiwa-peristiwa ilmiah (Astuti dkk, 2019). Pelajaran fisika salah satu pelajaran yang sangat di hindari oleh sebagian siswa karena merupakan pelajaran yang sangat sulit. Hal ini menyebabkan sebagian siswa mengalami kesulitan belajar dalam mata pelajaran fisika. Pembelajaran fisika terdapat persamaan-persamaan dan rumus fisika yang harus dihubungkan dalam konsep sehari-hari yang dirasa sulit untuk dipahami. Hal tersebut menyebabkan hasil belajar fisika yang diperoleh siswa untuk pelajaran fisika menjadi rendah. Berdasarkan observasi di SMP Negeri 87 Jakarta Selatan yang menyebabkan hasil belajar fisika rendah yaitu siswa hampir selalu diajar dengan metode ceramah yang kurang menarik, hal ini membuat siswa menerima pengetahuan secara abstrak dan siswa kurang terlibat dalam pembelajaran. Faktor-faktor tersebut dapat menyebabkan pembelajaran yang bermakna belum tercapai. Oleh karena itu diperlukan strategi pembelajaran yang bisa mengaktifkan siswa di kelas sehingga siswa bisa terlibat secara langsung dalam proses pembelajaran.

Salah satu strategi pembelajaran yang bisa digunakan yaitu strategi rangkaian konsep. Rangkaian konsep adalah suatu cara yang baik untuk mendapatkan ide baru dan cara yang mudah untuk mendapatkan informasi dari otak. Dengan menggunakan rangkaian konsep, cara kerja alami otak dapat dilibatkan dari awal. Hal ini berarti bahwa untuk mengingat kembali informasi selanjutnya akan menjadi lebih mudah (Buzan, 2010). Rangkaian konsep merupakan suatu bagan skematik untuk menggambarkan suatu pengertian konseptual seseorang dalam suatu rangkaian pernyataan. Rangkaian konsep selain menggambarkan konsep- konsep yang penting, juga menghubungkan antara konsep-konsep yang ada.rangkaian konsep dapat membuat fisika menjadi lebih menarik dan membuat siswa dapat mengidentifikasi dan menginterpretasi konsep-konsep dan prinsip-prinsip fisika dengan jelas. Hal ini 
sesuai dengan pendapat Ausubel (dalam Mundilarto, 2002) belajar akan mempunyai makna bagi siswa apabila dapat memperoleh pengetahuan baru. Belajar akan dikatakan bermakna jika terhubungnya ide-ide baru dengan struktur kognitif untuk membentuk pengetahuan baru. Hasil belajar sangat menentukan kondisi siswa ketika belajar (Okyranida, 2020). Jika siswa memiliki minat belajar yang tinggi pasti hasil belajarnya juga tinggi, begitu pula sebaliknya (Arlen dkk, 2020). Untuk mempermudah memahami konsep- konsep awal materi pelajaran yang akan diajarkan, diperlukan suatu strategi yang diterapkan kepada seluruh siswa, yaitu menggunakan rangkaian konsep. Kiranya rangkaian konsep ini dapat dipakai untuk memperbaiki hasil belajar yang rendah. Berdasarkan penjelasan tersebut akan diteliti tentang, "Penerapan Rangkaian Konsep dalam Pembelajaran untuk Meningkatkan Hasil Belajar Fisika pada Pokok Bahasan Gerak Lurus Siswa Kelas VIII. 6 SMP Negeri 87 Kota Jakarta Selatan

\section{METODE PENELITIAN}

Penelitian ini adalah penelitian tindakan kelas yang dilaksanakan di SMP Negeri 87 Jakarta Selatan Subjek penelitian adalah siswa kelas VIII 6 SMP Negeri 87 Jakarta Selatan tahun ajaran 2020/2021 yang berjumlah 35 siswa. Desain penelitian yang digunakan adalah penelitian tindakan kelas yang dilakukan dalam tiga siklus. Setiap siklusnya terdiri dari empat tahap yaitu perencanaan (planning), tindakan (action), pengamatan (observation), dan refleksi (reflection).

Metode pengumpulan data yang digunakan dalam penelitian ini meliputi metode tes dan metode observasi. Instrumen yang digunakan adalah tes evaluasi hasil belajar siswa dan angket observasi. Hasil belajar afektif dan psikomotorik siswa dinilai melalui lembar observasi yang terdiri dari dua aspek penilaian, pemberian skor pada lembar observasi menggunakan interval 1-4. Skor rata-rata setiap aspek penilaian dikonversikan ke dalam bentuk kualitatif. Sedangkan hasil belajar kognitif dianalisis menggunakan analisis rata-rata secara deskriptif.

Indikator keberhasilan penelitian ini dapat dikatakan berhasil dengan adanya peningkatan hasil belajar baik aspek kognitif, afektif, ataupun psikomotorik siswa secara signifikan dibandingkan sebelum perlakuan baik secara klasikal maupun individu. Sebagai tolak ukur keberhasilan penelitian tindakan kelas ini dapat dilihat dari hasil tes, jika hasil belajar siswa mencapai 70\% secara individual (sesuai KKM di SMP Negeri 87 Jakarta Selatan) dan 85\% secara klasikal (Mulyasa 2007). Untuk penilaian aspek afektif dan psikomotorik seorang siswa dikatakan tuntas belajar jika hasil belajar siswa mencapai $75 \%$ secara individual dan ketuntasan klasikal 75\% (Mulyasa, 2007).

\section{HASIL DAN PEMBAHASAN}

\section{Hasil Penelitian}

Penerapan rangkaian konsep dalam pembelajaran pada pokok bahasan gerak lurus dirancang untuk meningkatkan hasil belajar siswa. Penelitian pelaksanaan penerapan rangkaian konsep dalam pembelajaran pada pokok bahasan gerak lurus dilaksanakan dalam tiga siklus. Siklus I membahas tentang pengertian gerak, perbedaan jarak dan perpindahan serta perbedaan kelajuan dan kecepatan. Siklus II membahas tentang gerak lurus beraturan (GLB) dan siklus III membahas tentang gerak lurus berubah beraturan (GLBB).

Pelaksanaan penerapan rangkaian konsep dalam pembelajaran pada pokok bahasan gerak lurus berpedoman pada RPP dan LKS yang penyusunannya telah disesuaikan dengan silabus SMP. Selain itu, pelaksanaan pembelajaran juga ditunjang oleh lembar observasi ranah afektif dan ranah psikomotorik, serta soal evaluasi akhir siklus yang berbentuk soal pilihan ganda. Sintaks pembelajaran dengan penerapan rangkaian konsep dalam penelitian ini diawali dengan memberikan motivasi kepada siswa, yaitu dengan melakukan tanya jawab mengenai permasalahan dalam kehidupan sehari-hari yang berkaitan dengan materi yang akan diajarkan. Kemudian guru melakukan apersepsi, yaitu dengan mengajukan pertanyaan tentang materi sebelumnya yang berkaitan dengan materi yang akan dibahas.

Selanjutnya guru membagi siswa menjadi delapan kelompok yang terdiri dari empat anggota. Bersamaan dengan itu salah satu siswa membantu guru mengumpulkan tugas merangkum materi fisika yang diberikan guru pada hari sebelumnya.

Langkah selanjutnya yaitu guru dibantu beberapa siswa melakukan demonstrasi dengan melakukan eksperimen. Data hasil eksperimen dijadikan sebagai bahan kegiatan diskusi kelompok. Kemudian guru membagikan rangkaiankonsep yang belum sempurna kepada setiap siswa dan membimbing siswa melakukan diskusi kelompok untuk membahas hasil percobaan dan 
menyelesaikan rangkaian konsep yang belum sempurna. Setelah kegiatan diskusi kelompok selesai, guru membimbing kegiatan diskusi kelas membahas hasil eksperimen, diawali dengan menunjuk perwakilan beberapa siswa untuk mempresentasikan hasil diskusi kelompoknya, kemudian ditanggapi oleh siswa yang lain. Selanjutnya guru bersama siswa menyimpulkan hasil diskusi kelas mengenai hasil eksperimen.

Langkah pembelajaran berikutnya, guru kembali menunjuk perwakilan siswa untuk mempresentasikan hasil diskusi kelompok mengenai rangkaian konsep, yang kemudian ditanggapi oleh siswa yang lain. Selanjutnya guru bersama siswa menyimpulkan hasil diskusi kelas tentang rangkaian konsep. Setelah kesimpulan hasil diskusi diperoleh, guru mengevaluasi siswa secara individual melalui tes evaluasi akhir siklus.

Pelaksanaan pembelajaran pokok bahasan gerak lurus dengan langkah- langkah tersebut dapat meningkatkan hasil belajar siswa, karena dalam pembelajaran terdapat kegiatan percobaan dan diskusi yang dilakukan oleh siswa, sehingga dapat memberikan kesempatan kepada siswa untuk terlibat secara langsung dalam proses pembelajaran. Saat siswa terlibat secara fisik dan mental dalam proses pembelajaran, maka pengetahuan maupun konsep yang diperoleh siswa akan mudah diingat. Yulianto (2009) mengemukakan bahwa pembelajaran yang memberikan kesempatan pada siswa untuk terlibat secara langsung dalam proses pembelajaran akan memberikan hasil yang lebih baik dibandingkan dengan pembelajaran yang tidak memberikan kesempatan tersebut kepada siswa. Dengan demikian setelah proses pembelajaran selesai, siswa mendapatkan pengetahuan dan konsep, sehingga hasil belajar siswa dapat meningkat. Dale dalam (Dimyati, 2009) menambahkan, belajar yang baik adalah belajar melalui pengalaman langsung. Setelah siswa melakukan kegiatan demonstrasi, maka siswa akan memperoleh sejumlah informasi terkait pokok bahasan gerak lurus.

Siswa yang terlibat dalam kegiatan diskusi membutuhkan interaksi yang lebih aktif dengan siswa lain, sehingga akan memperoleh hasil yang optimal (Sumarni dkk, 2020). Hal ini sejalan dengan pendapat Buzan (2010) yang menyatakan bahwa rangkaian konsep akan mempermudah siswa dalam perencanaan, berkomunikasi, menjadi kreatif, mudah menyelesaikan masalah, memusatkan perhatian, mampu menyusun dan menjelaskan pikiran-pikiran, mengingat dengan lebih baik, belajar dengan lebih cepat dan efisien.

\section{Pembahasan}

1. Hasil Belajar Ranah Kognitif

Hasil belajar ranah kognitif siswa diukur melalui tes tertulis di setiap akhir siklus yang berbentuk soal pilihan ganda. Setelah dilakukan analisis hasil tes, diperoleh data mengenai nilai tertinggi, nilai terendah, nilai rata-rata dan ketuntasan klasikal pada siklus I, II, dan III yang disajikan pada Tabel 1.

Tabel 1. Hasil Belajar Ranah Kognitif Siswa

\begin{tabular}{cccc}
\hline Aspek Penilaian & Siklus I & Siklus II & Siklus III \\
\hline Nilai Tertinggi & 80 & 90 & 100 \\
Nilai Terendah & 40 & 40 & 50 \\
Nilai Rata-rata & 69,69 & 72,19 & 80,31 \\
Ketuntasan Klasikal & $71,88 \%$ & $78,13 \%$ & $87,50 \%$ \\
Gain score & 0,22 (rendah) & 0,42 (sedang) & \\
\hline
\end{tabular}

Berdasarkan Tabel 1, hasil belajar kognitif siswa mengalami peningkatan di setiap siklus. Peningkatan hasil belajar kognitif tersebut disebabkan oleh penerapan rangkaian konsep dalam kegiatan pembelajaran pada pokok bahasan gerak lurus. Penerapan rangkaian konsep pada pembelajaran melibatkan siswa untuk ikut berperan dalam proses pembelajaran, sehingga siswa terbiasa untuk belajar sebelum proses pembelajaran berlangsung. Dengan adanya keterlibatan siswa secara langsung, menjadi pendukung bagi peningkatan hasil belajar dan aktivitas siswa. Hal ini sesuai dengan pendapat Imaduddin dan Unggul (2012), yang mengatakan bahwa rangkaian konsep sangat efektif dalam meningkatkan hasil belajar fisika.

Dari hasil pengamatan pada siklus I menunjukkan bahwa hasil belajar kognitif siswa belum memenuhi indikator keberhasilan. Hal ini disebabkan siswa belum terbiasa belajar dengan menggunakan rangkaian konsep seperti yang diterapkan dalam penelitian ini, sehingga siswa masih mengalami kesulitan dalam melakukan kegiatan pembelajaran, baik pada pelaksanaan demonstrasi, diskusi, maupun presentasi. Keadaan tersebut sejalan dengan pendapat Djamarah (2006) yang menyatakan apabila siswa sudah terbiasa belajar dalam kondisi tertentu, maka siswa akan sulit untuk menyesuaikan diri apabila situasi tersebut diubah. 
Pada siklus I, prinsip keterlibatan langsung siswa tidak terlaksana secara optimal, dan alokasi waktu yang tersedia tidak cukup untuk melakukan kegiatan. Untuk meningkatkan hasil belajar kognitif, maka disusunlah rencana tindakan pada siklus II, yaitu guru menjelaskan agar siswa melakukan kegiatan sesuai dengan prosedur yang diarahkan, sehingga kegiatan pembelajaran dapat berjalan lancar dan waktu yang tersedia dapat dimanfaatkan secara maksimal.

Pada siklus II, hasil pengamatan menunjukkan bahwa hasil belar kognitif siswa mengalami peningkatan berkategori rendah. Kelemahan pada siklus II yaitu alokasi waktu yang tersedia masih belum cukup karena siswa merasa kesulitan saat melakukan kegiatan percobaan gerak lurus. Untuk memaksimalkan hasil belajar kognitif siswa, maka disusunlah rencana tindakan pada siklus III, yaitu guru memotivasi siswa agar bersungguh-sungguh dalam kegiatan pembelajaran. Hal ini dilakukan agar pemahaman yang diperoleh siswa maksimal. Seperti yang dikemukakan Sardiman (2006) bahwa memberikan motivasi kepada siswa berarti menggerakkan siswa untuk melakukan sesuatu atau ingin melakukan sesuatu.

Pada siklus III hasil belajar kognitif siswa mengalami peningkatan berkategori sedang. Peningkatan dikarenakan siswa telah terbiasa belajar dengan menggunakan rangkaian konsep seperti yang diterapkan dalam penelitian ini. Prinsip keterlibatan siswa secara langsung dalam pembelajaran dengan menerapkan rangkaian konsep terbukti dapat meningkatkan hasil belajar siswa.

\section{Hasil Belajar Ranah Afektif}

Hasil belajar ranah afektif siswa diketahui melalui pengamatan selama proses pembelajaran. Penilaian hasil belajar afektif pada penelitian ini bertujuan untuk mengetahui sikap atau perilaku siswa selama proses pembelajaran sedang berlangsung. Pada siklus I, hasil belajar afektif siswa belum memenuhi indikator keberhasilan. Selama proses pembelajaran, siswa kurang bertanggungjawab pada kewajibannya. Ini ditunjukkan dengan banyaknya siswa yang tidak menyelesaikan tugas dengan baik dan tepat waktu. Selain itu siswa juga tidak jujur saat diberi kesempatan untuk bertanya jika mengalami kebingungan terhadap materi. Siswa lebih memilih pasif atau bermain sendiri dalam kegiatan diskusi kelompok. Hal ini menunjukkan bahwa aspek tanggung jawab dan kejujuran siswa masih rendah. Untuk meningkatkan hasil belajar afektif, maka guru menyusun rencana tindakan pada siklus II, yaitu guru memberikan bimbingan dan motivasi kepada siswa agar dapat menyelesaikan tugas dengan baik dan tepat waktu. Pemberian motivasi ini dengan cara memberitahukan kepada siswa, bahwa siswa yang mengumpulkan tugas tepat waktu akan mendapatkan tambahan nilai.

Hasil pengamatan pada siklus II menunjukkan bahwa hasil belajar afektif mengalami peningkatan meskipun belum mencapai indikator keberhasilan dan kriterianya rendah. Peningkatan hasil belajar afektif tersebut terjadi karena siswa sudah mulai terbiasa belajar dengan sintaks dalam penelitian ini. Sebagian siswa sudah menyelesaikan tugas dengan baik dan tepat waktu. Pada kegiatan diskusi, masih terdapat beberapa siswa yang pasif menyampaikan pendapat, bermain dan tidak mendengarkan pendapat siswa yang sedang presentasi.

Untuk memaksimalkan hasil belajar afektif siswa, maka disusunlah rencana tindakan pada siklus III, yaitu guru memberikan bimbingan dan motivasi. Motivasi ini berupa pemberitahuan kepada siswa, bahwa siswa yang aktif bertanya dan menyampaikan pendapat dalam kegiatan diskusi akan mendapatkan tambahan nilai. Pada siklus III hasil belajar afektif siswa mengalami peningkatan dengan kriteria sedang dan sudah mencapai indikator keberhasilan. Peningkatan tersebut dikarenakan siswa sudah terbiasa belajar dengan langkah pembelajaran seperti dalam penelitian.

3. Hasil Belajar Ranah Psikomotorik

Hasil belajar ranah psikomotorik siswa diketahui melalui pengamatan selama proses pembelajaran. Menurut Davies, tujuan ranah psikomotorik berhubungan dengan keterampilan motorik, manipulasi benda atau kegiatan yang memerlukan koordinasi saraf dan koordinasi badan (Dimyati, 2009).

Menurut Simpson dalam Ragil \& Sukiswo (2011), kategori untuk ranah psikomotorik meliputi persepsi, kesiapan, gerakan terbimbing, gerakan terbiasa, gerakan kompleks, penyesuaian, dan kreativitas. Penilaian hasil belajar psikomotorik siswa dalam penelitian ini meliputi: menyiapkan alat dan bahan percobaan, serta melakukan percobaan.

Hasil pengamatan pada siklus II menunjukkan bahwa hasil belajar psikomotorik mengalami peningkatan meskipun belum mencapai indikator keberhasilan dan kriterianya rendah. Peningkatan hasil belajar psikomotorik tersebut terjadi karena siswa mulai terbiasa dengan langkah pembelajaran dalam penelitian ini. Kegiatan percobaan juga bukan untuk yang pertama kalinya bagi siswa, 
sehingga sebagian besar siswa tidak lagi mengalami kesulitan dalam menyiapkan alat dan bahan, serta melakukan percobaan. Untuk memaksimalkan hasil belajar psikomotorik siswa, maka disusunlah rencana tindakan pada siklus III, yaitu selain memberikan bimbingan, guru juga perlu memotivasi siswa agar bersungguh-sungguh dalam menyiapkan alat dan bahan maupun melakukan percobaan.

Pada siklus III hasil belajar psikomotorik siswa mengalami peningkatan dengan kriteria sedang dan sudah mencapai indikator keberhasilan. Peningkatan tersebut dikarenakan siswa sudah terbiasa dengan langkah pembelajaran dalam penelitian ini. Selain itu kegiatan percobaan sudah berulang kali dilakukan siswa, sehingga siswa tidak mengalami kesulitan dalam menyiapkan alat dan bahan, serta melakukan percobaan.

Hasil belajar psikomotorik sangat penting untuk ditingkatkan dalam pembelajaran, karena sains khususnya fisika berkaitan dengan cara mencari tahu tentang alam secara sistematis, sehingga sains bukan hanya penguasaan kumpulan pengetahuan yang berupa fakta-fakta, konsep-konsep, atau prinsip-prinsip saja tetapi juga merupakan suatu proses penemuan (Subagiyadi dkk, 2020). Pembelajaran sains fisika di sekolah diharapkan dapat menjadi wahana bagi siswa untuk mempelajari diri sendiri dan alam sekitar.

\section{PENUTUP}

Berdasarkan hasil penelitian di kelas VIII.6 SMP Negeri 87 Jakarta Selatan disimpulkan bahwa penerapan rangkaian konsep dalam pembelajaran dapat meningkatkan hasil belajar fisika, baik untuk aspek kognitif, afektif maupun psikomotorik siswa pada pokok bahasan gerak lurus. Penerapan rangkaian konsep dalam pembelajaran pokok bahasan gerak lurus dilaksanakan kepada siswa dengan seluruh rangkaian pembelajaran yaitu pemberian motivasi, penyampaian apersepsi, melakukan kegiatan percobaan, diskusi kelompok tentang hasil percobaan dan menyelesaikan rangkaian konsep yang belum sempurna, presentasi hasil diskusi kelompok, menanggapi presentasi, dan membuat kesimpulan pembelajaran. Dalam satu rangkaian siklus diakhiri dengan pelaksanaan tes evaluasi untuk mengetahui peningkatan hasil belajar kognitif siswa. Sedangkan lembar observasi digunakan untuk mengamati peningkatan hasil belajar afektif dan psikomotorik siswa.

Berdasarkan hasil penelitian, saran yang dapat disampaikan peneliti kepada guru IPA, yaitu untuk meningkatkan hasil belajar siswa hendaknya memadukan rangkaian konsep dengan model atau metode pembelajaran yang lain secara silih berganti agar siswa tidak jenuh dengan pembelajaran yang dilakukan. Saran yang selanjutnya disampaikan untuk peneliti lain, yaitu hendaknya dapat meneliti aspek hasil belajar afektif dan psikomotorik yang lainnya. Selain itu selama proses pengamatan hasil belajar afektif dan psikomotorik dilakukan oleh observer dengan jumlah yang sesuai, hal ini dimaksudkan agar proses pengamatan dapat dapat dilakukan dengan lebih maksimal.

\section{DAFTAR PUSTAKA}

Arlen, S. R., Astuti, I. A. D., Fatahillah, F., \& Purwanti, P. (2020). Pengaruh Media Pembelajaran Fisika Menggunakan Aplikasi Appypie Terhadap Hasil Belajar Fisika Siswa di SMK. Schrodinger Jurnal Ilmiah Mahasiswa Pendidikan Fisika, 1(1), 44-49.

Astuti, I. A. D., Dewati, M., Okyranida, I. Y., \& Sumarni, R. A. (2019). Pengembangan media smart powerpoint berbasis animasi dalam pembelajaran fisika. Navigation Physics: Journal of Physics Education, 1(1), 12-17.

Buzan, T. (2010). Buku Pintar Mind Map. Jakarta: Gramedia Pustaka Utama.

Dimyati, M. (2009). Belajar \& Pembelajaran. Jakarta: Rineka Cipta.

Djamarah. (2006). Strategi Belajar Mengajar. Jakarta: Rineka Cipta.

Imaduddin, M. C., \& Utomo, U. H. N. (2012). Efektifitas metode mind mapping untuk meningkatkan prestasi belajar fisika pada siswa kelas VIII. Humanitas: Jurnal Psikologi Indonesia, 9(1), 62-75.

Mulyasa. (2007). Kurikulum Tingkat Satuan Pendidikan. Bandung: PT Remaja Rosdakarya. 57

Mundilarto, M. (2002). Posisi dan Peranan Strategis Pengajaran IPA (Fisika) di Sltp. Jurnal Cakrawala Pendidikan, 3(3).

Okyranida, I. Y. (2020). Penerapan Pembelajaran Berbasis Proyek dengan E-Learning untuk Meningkatkan Kreativitas dan Hasil Belajar Mahasiswa pada Mata Kuliah IPA Terpadu. Navigation Physics: Journal of Physics Education, 2(1), 36-40.

Ragil, Z., \& Sukiswo, S. E. (2011). Penerapan pembelajaran sains dengan pendekatan sets pada materi cahaya untuk meningkatkan hasil belajar siswa kelas V SD. Jurnal Pendidikan Fisika Indonesia, 7(1). 
Sardiman, M. (2006). Motivasi Dan Interaksi Belajar Mengajar. Jakarta: Raja Grafindo Persada.

Subagiyadi, P., Bhakti, Y. B., \& Mulyaningsih, N. N. (2020). Pengaruh Metode Pembelajaran Inquiry Pictorial Riddle Terhadap Hasil Belajar Fisika Pada Sekolah Menengah Atas Negeri 85 Jakarta. Navigation Physics: Journal of Physics Education, 2(1), 41-46.

Sumarni, R. A., Bhakti, Y. B., Astuti, I. A. D., Sulisworo, D., \& Toifur, M. (2020). Analisis Kebutuhan Guru Smp Mengenai Metode Pembelajaran Flipped Classroom. ORBITA: Jurnal Kajian, Inovasi dan Aplikasi Pendidikan Fisika, 6(2), 236-242.

Yulianto \& Rusmiyati. (2009). Peningkatan Keterampilan Proses Sains Dengan Menerapkan Model Problem Based-Instruction. Jurnal Pendidikan Fisika Indonesia, 5: 75-78. 